\title{
Effects of Culture Media on Viability of Beauveria Bassiana and Its Pathogenicity Against Coffee Bean Borer (Hyphotenemus Hampei)
}

\author{
R.R. Rukmowati Brotodjojo*, Chimayatus Solichah, Anindita Widyaningtyas, Danar Wicaksono \\ Universitas Pembangunan Nasional Veteran Yogyakarta \\ Jl. Padjadjaran 104, Condongcatur, Yogyakarta, 55283, Indonesia \\ Ph. +62274486733; Fax. +62274486400 \\ Email*: brotodjojo@upnyk.ac.id
}

\begin{abstract}
Coffee bean borer (Hypothenemus hampei) attacks coffee when it is still in the plantation until it is in the storage that reduce the quality of coffee. To avoid the negative impact of chemical insecticides, biological control is carried out by using entomopathogen Beauveria bassiana. The aims of this research were to study the effects of culture media on viability of $B$. bassiana and its pathogenicity in controlling H. hampei. Laboratory experiment was arranged in Completely Random Design (CRD). This research used 8 (eight) treatments namely KO: Distilled water, Kk: Lamda Sihalothrin $25 \mathrm{EC}$ (Chemical Insecticide), B1: $10 \mathrm{~g} / \mathrm{L}$ B. bassiana cultured in rice bran media, B2: $20 \mathrm{~g} / \mathrm{L}$ B. bassiana cultured in rice bran media, B3: $30 \mathrm{~g} / \mathrm{L}$ B. bassiana cultured in rice bran media, B4: $10 \mathrm{~g} / \mathrm{L}$ B. bassiana cultured in corn media, B5: $20 \mathrm{~g} / \mathrm{L}$ B. bassiana cultured in corn media and B6: $30 \mathrm{~g} / \mathrm{L}$ B. bassiana cultured in corn media. Each treatment was applied on coffee beans infested with $20 \mathrm{H}$. hampei and repeated 4 (four) times. The results showed that rice bran media produced the highest number of spores with highest viability. The application of $B$. bassiana could killed $H$. hampei. The concentration of $30 \mathrm{~g} / \mathrm{L}$ of $B$. bassiana cultured in rice bran media resulted in the fastest mortality (Mortality time and Lethal Time 50\%) of H. hampei.
\end{abstract}

Keywords: Beauveria bassiana, Hypothenemus hampei, chemical insecticide, coffee beans

\section{INTRODUCTION}

Coffee is a world trade commodity that has high export value. Coffee berry borer (Hypothenemus hampei) is a major pest causing a decrease in coffee production both in quantity and quality (Barrera, 2008). The farmers still rely on the use of synthetic chemical pesticides which are considered to be less effective because almost all stages of $H$. hampei development are located in the fruit (Barrera, 2008). To reduce the negative impact of the use of synthetic pesticides, biological control attempts are carried out by spraying the fungus Beauveria bassiana which is a natural enemy of the pest and has specific properties for controlling several types of pests (Vega et al., 1995, Yasuda, 1999, Lyons et al., 2012). Based on research conducted by Solichah \& Brotodjojo (2010), it was found that the best source of nutrition for making media for the production of $B$. bassiana fungus was rice bran, in comparison to corn or rice. The growth of $B$. bassiana spores at 10 days and 15 days after inoculation was most obvious in media made of rice bran and followed by a mixture of corn + rice bran compared to the media of rice, corn, rice + corn mixture or rice + rice bran mixture. This can be seen from the average number of spores in rice bran media considerably higher than other media because of the presence of nutrient content and a higher surface area than other media.

Kansrini (2015) also found that rice bran media was better to support the growth of $B$. bassiana fungus than corn media. The results of the study showed that in rice bran and cassava media, the spore density was higher than that of yam and corn, i.e., $1,672,600,000$ spores/gram and 1,650,133,333 spores/gram, respectivelly. The spore density in yam and corn media, was $1,546,933,333$ spores/gram and 1,255,933,333 spores/gram, respectively. However, the highest viability of $B$. bassiana spores was found in yam media $(97.42 \%)$, followed by cassava media $(96.77 \%)$, potatoes media $(95.99 \%)$, corn $(95.46 \%)$ and rice bran media $(92.55 \%)$. Murhadinata (2017) found that B. bassiana propagated on black rice media and diluted in distilled water with a concentration of $10 \mathrm{~g} / \mathrm{L}, 20 \mathrm{~g} / \mathrm{L}, 30 \mathrm{~g} / \mathrm{L}$ in comparison to control (without $B$. bassiana) caused average total mortality time $(100 \%)$ of $H$. hampei for 10 days; 9.3 days; 8 days and 0 days, respectivelly. The concentration that caused the most rapid mortality was the concentration of $30 \mathrm{~g} / \mathrm{L}$ with LT 52 (52\% mortality) which can be achieved on day 5 . This is consistent with the results of Sari (2014), that found M. anisopliae which was propagated on milled corn media with a concentration of $5 \mathrm{~g} / \mathrm{L}, 10 \mathrm{~g} / \mathrm{L}, 15 \mathrm{~g} / \mathrm{L}$, and $20 \mathrm{~g} / \mathrm{L}$ and control (without $M$. anisopliae) caused average total mortality time (100\%) of $\mathrm{H}$. hampei for 13 days; 12 days; 11.67 days; 10 days and 0 days. The concentration that caused the most rapid death was the concentration of $20 \mathrm{~g} / \mathrm{L}$ distilled water with $80 \mathrm{LT}$ (80\% mortality) that obtained on the 8th day.

Tanjung et al. (2011) tested the B. bassiana Wamena strain in spore powder formulation with various spores concentration i.e., $0.10 \mathrm{~g} / \mathrm{L} ; 0.20 \mathrm{~g} / \mathrm{L} ; 0.30 \mathrm{~g} / \mathrm{L} ; 0.40 \mathrm{~g} / \mathrm{L}$; and $0.50 \mathrm{~g} / \mathrm{L}$ applied to $H$. hampei imago. The $B$. bassiana $0.50 \mathrm{~g} / \mathrm{L}$ treatment was the best treatment with 
an average mortality of $71.77 \%$, followed by the treatment of $0.40 \mathrm{~g} / \mathrm{L}(58.14 \%) ; 0.30 \mathrm{~g} / \mathrm{L}(47.29 \%) ; 0.20$ $\mathrm{g} / \mathrm{L}(41.01 \%) ; 0.10 \mathrm{~g} / \mathrm{L}(37.32)$ and control (0.45\%). In the other hand, Yuwirawan (2011) found that treatment that caused the highest total mortality on $H$. hampei imago was $3 \mathrm{~g} / \mathrm{L} \mathrm{B}$. bassiana $(80 \%)$ with the highest mortality rate on day 1 and 4 , followed by $5 \mathrm{~g} / \mathrm{L} B$. bassiana (78\%), with the highest mortality on day 4 , treatment of $1 \mathrm{~g} / \mathrm{L} \mathrm{B}$. bassiana $(72 \%)$. with the highest mortality rate on day 3 and control treatment (68\%) with the highest mortality rate on days 1 and 5. Considering that different culture media will result in different spores number and viability of spores that subsequently affect the pathogenicity of entomopathogenic fungi, this reseach aimed to study the effect of culture media on the viability and pathogenicity of $B$. bassiana on H. hampei.

\section{MATERIALS AND METHODS}

\section{Preparation Step}

Rearing of Test Insect Hypothenemus hampei

Exploration to collect $H$. hampei was carried out at the Experimental Garden of the Plantation and Forestry Agency located in Ngipiksari. Hypothenemus hampei adults were taken to the laboratory to be separated from the infested coffee beans. Then $H$. hampei adults were placed in a plastic jar that contained healthy coffee beans and wet cotton for rearing.

\section{Beauveria bassiana Propagation}

Pure cultures of $B$. bassiana fungus were obtained from the Yogyakarta Forestry and Plantation Office of Plant Protection Agency, which originated from infected $H$. hampei pests and then cultured on solid media as material for propagation. The materials (rice bran and corn) were cleaned and washed with water, steamed until half-cooked using a steamer, and then quenched with warm water and stirred. Half cooked rice bran and corn were placed on the table to be dried. Chloramphenicol solution as an anti-bacterial agent then was mixed with the media evenly. The media was placed in an Erlenmeyer as much as $200 \mathrm{~mL}$ and covered with aluminum foil for sterilization using an autoclave. After the media was sterile, the $B$. bassiana isolate was inoculated into the media and incubated at room temperature for one week until the F1 fungus is produced. The F1 fungus was inoculated again into new propagation media and incubated for one week until the F2 fungus was produced.

\section{Preparation of Beauveria bassiana Suspension}

F2 fungus was diluted into suspensions with various concentrations to be used for testing the quality of fungal spores and testing pathogenicity of $B$. bassiana against $H$. hampei. To test the quality of spores, $1 \mathrm{~g}$ of $B$. bassiana was dissolved into $100 \mathrm{~mL}$ of sterile distilled water. To test the pathogenicity of $B$. bassiana against $H$. hampei, $10 \mathrm{~g}, 20 \mathrm{~g}$, and $30 \mathrm{~g}$ of $\mathrm{B}$. bassiana were dissolved respectively in $1 \mathrm{~L}$ of sterile distilled water. Before B. bassiana suspension was applied to $H$. hampei, the number of spores per concentration was calculated. The controls used were negative control with distilled water without $B$. bassiana and positive control with a chemical insecticide Lamda Sihalotrin 25 EC (3 $\mathrm{mL}$ dissolved in $1 \mathrm{~L}$ sterile distilled water).

\section{Testing Step}

The experiment was arranged according to a Completely Randomized Design (CRD). The treatments were KO: Distilled water, Kk: Lamda Sihalothrin 25 EC (Chemical Insecticide), B1: $10 \mathrm{~g} / \mathrm{L} \mathrm{B.} \mathrm{bassiana} \mathrm{cultured} \mathrm{in} \mathrm{rice} \mathrm{bran}$ media, B2: $20 \mathrm{~g} / \mathrm{L}$ B. bassiana cultured in rice bran media, B3: $30 \mathrm{~g} / \mathrm{L}$ B. bassiana cultured in rice bran media, B4: $10 \mathrm{~g} / \mathrm{L}$ B. bassiana cultured in corn media, B5: $20 \mathrm{~g} / \mathrm{L}$ B. bassiana cultured in corn media and B6: $30 \mathrm{~g} / \mathrm{L} \mathrm{B}$. bassiana cultured in corn media. with four replicates. The $B$. bassiana suspension, Lamda Sihalotrin $25 \mathrm{EC}$ and distilled water without $B$. bassiana (control) each was applied on a batch of twenty $H$. hampei.

\section{Spore Quality Test of B. bassiana}

1. Number of Spores

Spores are calculated by the formula:

$$
\mathrm{S}=\frac{\mathrm{t} \times \mathrm{d}}{\mathrm{n} \times 0,25} \times 10^{6}
$$

$\mathrm{S}=$ number of spores per gram of media (spores/mL)

$\mathrm{t}=$ number of spores calculated in the calculation box (a, b, c, d, and e)

$\mathrm{d}=$ dilution rate $(100 \mathrm{~mL})$

$\mathrm{n}=$ number of small boxes observed (i.e : $5 \times 16=$ 80 small boxes)

$10^{6}=$ constant value with a 100 times dilution rate

2. Spore Viability

$$
\text { Viability }=\frac{\text { Number of Germinated Spores }}{\text { Total Spores Observed }} \times 100 \%
$$

Pathogenicity Test of H. hampei

1. Mortality Rate

$$
\mathrm{V}=\frac{\mathrm{T} 1 \mathrm{~N} 1+\mathrm{T} 2 \mathrm{~N} 2+\cdots+\mathrm{TnNn}}{\mathrm{n}}
$$

Note :

$\mathrm{V}=$ Mortality rate after application (Days)

$\mathrm{T}=$ Observation time at a certain time

$\mathrm{N}=$ Number of $H$. hampei died at a certain time

$\mathrm{n} \quad=$ Number of $H$. hampei within the test at each replication

2. LT 50

LT50 (Lethal Time 50\%) is the time observed when $50 \%$ of tested insects die. 


\section{Data analysis}

To analyze the quality of $B$. bassiana, data of number of spores and spore viability were subjected to t-test $(\alpha=5 \%)$ and to test the pathogenicity of $B$. bassiana against $H$. hampei, mortality data was subjected to analysis of variance $(\alpha=5 \%)$ followed by Duncan Multiple Range Test (DMRT) $(\alpha=5 \%)$ for LT50 (Lethal Time 50\%) and Contrast Orthogonal $(\alpha=5 \%)$ for the rate of mortality. Data analysis was assisted by Microsoft Excel and SPSS (Statistical Package for the Social Sciences).

\section{RESULTS AND DISCUSSION}

\section{Number of Spores (Spores $/ \mathrm{mL}$ ) and Spores Viability (\%)}

Table 1 shows that the average number of spores and viability of $B$. bassiana spores cultured on rice bran media were significantly higher than those of $B$. bassiana cultured on corn media.

Table 1. The average number of spores and viability of B. bassiana spores cultured on rice bran and corn media.

\begin{tabular}{|c|c|c|}
\hline $\begin{array}{l}\text { Type of } \\
\text { Media }\end{array}$ & $\begin{array}{l}\text { Number of Spores } \\
\text { (spores/mL) }\end{array}$ & Viability (\%) \\
\hline \multirow[t]{3}{*}{ Rice Bran } & $7,90 \times 10^{8}$ & 88,04 \\
\hline & $9,45 \times 10^{8}$ & 90,42 \\
\hline & $8,70 \times 10^{8}$ & 89,69 \\
\hline Average & $8,68 \times 10^{8} a$ & 89,38 a \\
\hline \multirow[t]{3}{*}{ Corn } & $2,25 \times 10^{8}$ & 82,69 \\
\hline & $2,15 \times 10^{8}$ & 82,97 \\
\hline & $2,30 \times 10^{8}$ & 83,01 \\
\hline Average & $2,23 \times 10^{8} b$ & 82,89 b \\
\hline
\end{tabular}

Note: value in the same column followed by the same letter indicates that there is no significant difference based on the t-level test of $5 \%$ level.

The density or number of spores $\geq 10^{6}$ spores $/ \mathrm{mL}$ is categorized as good formulation quality (Directorate of Plantation Protection of the Ministry of Agriculture, 2014), so that in relation to the quality of spores, $B$. bassiana cultured in rice bran and corn media were categorized as good, but the rice bran media had significantly higher number of spores than corn media (Table 1). The number of fungi spores are influenced by various factors such as surface area and nutrition content in the propagation media used. The surface area covered with fungi in rice bran media is higher than corn media in the equivalent volume. The entomopathogenic fungus requires media with high glucose and protein content. Nutritional content (protein, fat, minerals, calcium, iron and thiamine) in rice bran is higher than corn (Solichah and Brotodjojo, 2010).

Spore viability is the ability of spores to germinate. A good percentage of spore germination is at least $60 \%$ (Directorate of Plantation Protection of the Ministry of
Agriculture, 2014). The fungi in both media had a good percentage of spore germination because it has exceeded the minimum limit. Results of fungal spore viability revealed that rice bran media had significantly higher spore viability than corn media (Table 1). The entomopathogenic fungi requires media with high sugar and protein content (Agus et al., 2015). Beauveria bassiana needs carbon to support germination. The source of carbon can be from glucose, $N$ acetylglucosamine, glucosamine, chitin, starch, lanolin, hydrocarbons in crude oil, and some longer-chain fatty acids. Furthermore, it requires a source of nitrogen for hyphal growth (Smith \& Grula, 1981). Protein content in the rice bran is higher than corn. Proteins on the surface of conidia are involved in a variety of important functions. In particular, these proteins contribute to germination, stress resistance, adhesion to substrates, and virulence (Blango et al., 2019). Proteins is needed for organelle formation, which has a role in the formation of apical hyphae and enzyme synthesis (Garraway and Evans, 1984).

\section{Mortality Rate}

The observation on mortality shows that positive control using the chemical pesticide Lamda Sihalotrin 25 EC caused $100 \%$ mortality of $H$. hampei one day after application. The active substance of Lamda Sihalotrin 25 EC can kill directly by absorption through the skin of $H$. hampei at the time of application (Murhadinata, 2017). In the treatment of biological agents, $30 \mathrm{~g} / \mathrm{L} \mathrm{B}$. bassiana cultured on rice bran media significantly caused a higher percentage of $H$. hampei mortality compared to other concentrations (Table 2). According to Atmadja et al. (2000) the higher the conidia concentration of $B$. bassiana, the higher the insect mortality rate than other concentrations.

The average mortality rate of $H$. hampei by Lamda Sihalotrin $25 \mathrm{EC}$ was significantly faster than other treatments. The treatment of biological agent $B$. bassiana cultured on rice bran media significantly caused mortality faster than $B$. bassiana cultured on corn media. All concentrations in the B. bassiana cultured on rice bran media group were not significantly different (Table 2). Application of $30 \mathrm{~g} / \mathrm{L} \mathrm{B}$. bassiana cultured on rice bran media had a higher number of spores and spore viability than other treatment. The successful use of entomopathogenic fungus in pest control is determined by the conidia density and spore germination rate, the higher the density and germination capacity, the chance of fungus in killing insects is also faster and vice versa. Biological agents caused the mortality of $H$. hampei slower than chemical treatment because biological agents must went through several stages to infect and kill insects. Beauveria bassiana requires several stages process to infect and kill insects, namely the attachment of conidia on the insect's body, germination, penetration and invasion, and destruction (Keswani et al, 2013). 
Table 2. Mortality rate of $H$. hampei.

\begin{tabular}{|c|c|c|c|}
\hline Treatments & $\begin{array}{l}\text { Mortality Rate } \\
\text { (days) }\end{array}$ & $\underset{[}{\frac{\mathscr{J}}{\tilde{J}}}$ & $\begin{array}{l}20 \\
\text { in } \\
\frac{0}{0} \\
\frac{1}{\sigma} \\
{[}\end{array}$ \\
\hline $\mathrm{KO}><\mathrm{Kk} \mathrm{B}_{1,2,3,4,5,6}$ & $0><13,32$ & $4,513^{*}$ & 4,260 \\
\hline $\mathrm{Kk}><\mathrm{B}_{1,2,3,4,5,6}$ & $1><15,37$ & $4,958^{*}$ & 4,260 \\
\hline $\mathrm{B}_{1,2,3}><\mathrm{B}_{4,5,6}$ & $13,95><16,79$ & $27,947 *$ & 4,260 \\
\hline $\mathrm{B} 1><\mathrm{B}_{2,3}$ & $15,59><13,13$ & $1,423 \mathrm{~ns}$ & 4,260 \\
\hline $\mathrm{B} 2><\mathrm{B} 3$ & $13,91><12,36$ & $1,313 \mathrm{~ns}$ & 4,260 \\
\hline $\mathrm{B} 4><\mathrm{B}_{5,6}$ & $18,88><15,75$ & $23,877 *$ & 4,260 \\
\hline $\mathrm{B} 5><\mathrm{B} 6$ & $16,81><14,69$ & $10,499 *$ & 4,260 \\
\hline
\end{tabular}

Note: Based on contrast orthogonal test $(\alpha=5 \%)$, there is a significant difference if $\mathrm{F}$ calculate $>\mathrm{F}$ table.

$(*)$ : there is a significant difference in comparison between treatments. ns: there is no significant difference in comparison between treatments.

\section{Lethal Time $50 \%$}

The DMRT test at the 5\% test level in Table 3 shows that the average $50 \%$ lethal time of $H$. hampei caused by B. bassiana cultured on rice bran concentrations of $30 \mathrm{~g} /$ L was significantly faster than other treatment.

Table 3. Lethal Time $50 \%$ (LT 50) of H. hampei (days).

\begin{tabular}{|c|c|c|c|c|c|}
\hline \multirow{2}{*}{$\begin{array}{l}\text { Treatments } \\
\text { Symbol }\end{array}$} & \multicolumn{4}{|c|}{ Replication } & \multirow{2}{*}{$\begin{array}{c}\text { Average } \\
\text { (Days) }\end{array}$} \\
\hline & 1 & 2 & 3 & 4 & \\
\hline $\begin{array}{l}10 \mathrm{~g} / \mathrm{L} \text { B.bassiana } \\
\text { in rice bran media } \\
\text { (B1) }\end{array}$ & 17,12 & 17,99 & 18,37 & 16,52 & $17,50 \mathrm{~cd}$ \\
\hline $\begin{array}{l}20 \mathrm{~g} / \mathrm{L} \text { B.bassiana } \\
\text { in rice bran media } \\
\text { (B2) }\end{array}$ & 15,47 & 15,99 & 15,52 & 14,79 & $15,44 \mathrm{~b}$ \\
\hline $\begin{array}{l}30 \mathrm{~g} / \mathrm{L} \text { B. bassiana } \\
\text { in rice bran media } \\
\text { (B3) }\end{array}$ & 14,27 & 13,67 & 13,65 & 14,95 & $14,14 \mathrm{a}$ \\
\hline $\begin{array}{l}10 \mathrm{~g} / \mathrm{L} \text { B.bassiana } \\
\text { in corn media } \\
\text { (B4) }\end{array}$ & 20,77 & 19,87 & 20,07 & 18,36 & $19,77 \mathrm{e}$ \\
\hline $\begin{array}{l}20 \mathrm{~g} / \mathrm{L} \text { B.bassiana } \\
\text { in corn media } \\
\text { (B5) }\end{array}$ & 19,47 & 17,26 & 18,13 & 18,36 & $18,30 \mathrm{~d}$ \\
\hline $\begin{array}{l}30 \mathrm{~g} / \mathrm{L} \text { B.bassiana } \\
\text { in corn media } \\
\text { (B6) }\end{array}$ & 17,38 & 15,88 & 16,79 & 17,06 & $16,78 \mathrm{c}$ \\
\hline
\end{tabular}

Note: Values followed by the same letter in one column indicate no significant difference based on Duncan's multiple range test at the 5\% level. (Data is transformed with arcsin $\mathrm{x}$ before statistical analysis).

The results showed that $30 \mathrm{~g} / \mathrm{L}$ B. bassiana cultured in rice bran media was significantly causing $50 \%$ mortality (LT 50) faster from the total $H$. hampei observed than other treatments (Table 3). The smaller the LT 50 value, the faster the treatment infects and kills $50 \%$ of the total $H$. hampei observed. The fungus $B$. bassiana takes more time to cause the motality on insect which is about five days (Keswani et al, 2013). Factors affect the infection of diseases in insects are the contact of the fungus with the insect's body. The higher the concentration, the more conidia come in direct contact with the body of the insect, so that the penetration and infection of conidia fungus that successfully germinate will occur more quickly (Hasnah, 2012).

\section{CONCLUSION}

Beauveria bassiana can cause $100 \%$ mortality of $H$. hampei within 19.25 to 28.50 days. The best propagation media for $B$. bassiana which produces high numbers of spores and viability of spores was rice bran. The best concentration with high pathogenicity was $30 \mathrm{~g} / \mathrm{L} B$. bassiana cultured on rice bran media. Further studies are needed on other propagation media that are possible to provide better growth so that the level of pathogenicity can increase.

\section{ACKNOWLEDGEMENTS}

The authors would like to thank the Institute for Research and Community Services for providing research funding through the 2019 Applied Research Grant scheme, and also Plant Protection Agency of the Forestry and Plantation Service of the Special Region of Yogyakarta, which became the research partner so that this research could be carried out.

\section{REFERENCES}

Agus N, Saranga AP, Rosmana A, Sugiarti A. 2015. Viability and Conidial Production of Entomopathogenic Fungi Penicillium sp. International Journal of Scientific and Technology Research, Vol. 4 (1): 193-195

Barrera, JF. 2008. Coffee Pests and their Managment. 2nd ed. Encyclopedia of Entomology. Springer. pp. 961-998.

Blango MG, Kniemeyer O, Brakhage AA. 2019. Conidial Surface Proteins at the Interface of Fungal Infections. PLOS Pathogens 15 (9): 1-8. $\quad$ DOI: https://doi.org/10.1371/journal.ppat.1007939.

Directorate of Plantation Protection. 2014. Pedoman Uji Mutu dan Efikasi Lapangan Agens Pengendalian Hayati (APH). Direktorat Perlindungan Perkebunan, Kementrian Pertanian. $115 \mathrm{p}$.

Garraway MO, Evans RC. 1984. Fungal Nutrition and Physiology. John Wiley and Sons. New York.

Hasnah, Susanna, dan Husin S. 2012. Keefektifan Cendawan Beauveria bassiana Vuill terhadap Mortalitas Kepik Hijau Nezara viridula L. pada Stadia Nimfa dan Imago. Jurnal Floratek. 7 (13): 24.

Kansrini Y. 2015. Uji Berbagai Jenis Media Perbanyakan Terhadap Perkembangan Jamur Beauveria bassiana di Laboratorium. Jurnal Agrica Ekstensia. 9 (1): 34-39.

Keswani C, Singh SP, Harikesh Bahadur Singh HB, 2013. Beauveria bassiana: Status, Mode of action, Applications and 
Safety issues. Biotech Today 3 (1): 16-20. DOI : 10.5958/j.2322-0996.3.1.002

Lyons DB, Lavallée R, Kyei-Poku G, Kees VF, Johny S, Guertin C, Francese JA, Jones GC, Blais M. 2012. Towards the Development of an Autocontamination Trap System to Manage Populations of Emerald Ash Borer (Coleoptera: Buprestidae) with the Native Entomopathogenic Fungus, Beauveria bassiana. Journal of Economic Entomology, 105: 1929-1939

Murhadinata. 2017. Pengaruh Konsentrasi Inokulum Beauveria bassiana Pada Beras Hitam Terhadap Tingkat Kematian Hama Penggerek Buah Kopi Hypothenemus hampei (Ferrari). [Skripsi]. Fakultas Matematika dan Ilmu Pengetahuan Universitas Ahmad Dahlan Yogyakarta.

Sadad A, Mahanani TA, Evie R. 2014. Pemanfaatan Bekatul Padi, Bekatul Jagung, dan Kulit Ari Biji Kedelai sebagai Media Pertumbuhan Miselium Cendawan Metarhizium anisopliae. Jurnal Lentera Bio 3(2): 136-140

Sari LA. 2014. Uji Patogenitas Spora Jamur Metharhizium anisopliae Terhadap Mortalitas Hama Hypothenemus hampei (Ferrari) Sebagai Bahan Ajar Biologi SMA Kelas X. JUMPEMASI-PBIO. 1 (1): 26-32.

Smith RJ, Grula EA. 1981. Nutritional requirements for conidial germination and hyphal growth of Beauveria bassiana. Journal of Invertebrate Pathology 37(3): 222-230
Solichah C, Brotodjojo R. 2010. Perbanyakan Jamur Entomopatogen Beauveria bassiana Pada Berbagai Macam Media Padat Untuk Pengendalian Phyllophaga spp. Prosiding Seminar Nasional Ketahanan Pangan \& Energi, Yogyakarta, 2 Desember 2010. Fakultas Pertanian Universitas Pembangunan Nasional "Veteran" Yogyakarta.

Tanjung HR, Kamarea M, Yepese YP. 2011. Uji Patogenits Spora Beauveria bassiana Strain Wamena Sebagai Agen Hayati Terhadap Hama Penggerek Buah Kopi Hypothenemus hampei. Jurnal Biologi Papua. 3, (1): 9-15.

Vega FE, Dowd PF, Bartelt RJ. 1995. Dissemination of Microbial Agents Using an Autoinoculating Device and Several Insect Species as Vectors. Biological Control 5: 545-552.

Yasuda K. 1999. Auto-Infection System for the Sweet Potato Weevil, Cylas formicarius (Fabricius) (Coleoptera: Curculionidae) With Entomopathogenic Fungi, Beauveria bassiana Using A Modified Sex Pheromone Trap In The Field. Applied Entomology and Zoology 34: 501-505.

Yuwirawan IM. 2011. Efektivitas Jamur Beauveria bassiana dalam Pengendalian Hama Penggerek Buah Kopi (Hypothenemus hampei). [Skripsi]. Fakultas Pertanian Institut Pertanian Stiper Yogyakarta. 
THIS PAGE INTENTIONALLY LEFT BLANK 